\title{
Cultural Characteristics of Recombinant Escherichia coli Cells Carrying a Novel Antioxidant Gene
}

\author{
Duduku Krishnaiah ${ }^{\star}$, Awang Bono, Rosalam Sarbatly \\ Chemical Engineering Programme, School of Engineering and Information Technology \\ Universiti Malaysia Sabah, 88999 Kota Kinabalu, Sabah \\ E-mail: krishna@ums.edu.my
}

\begin{abstract}
Oxidative stress was studied in terms of reactive oxygen species (ROS) in superoxide dismutase deficient $E$. coli IM303 (I4) carrying pYGE and pUC 19 vector in a bioreactor to investigate cultural characteristics of the cells. The maximum specific growth rate was found for both cultures and the parameters were evaluated with Gompertz equation. The yield of pYGE was 1.5 times higher than that of the cells carrying pUC 19, indicating that the cell carrying pYGE can grow effectively under an oxidative stress condition. It was also found that the DO values were varied with pUC19 than pYGE and the ROS content of pUC19 was found to be higher than PYGE.
\end{abstract}

Keywords: Escherichia coli, reactive oxidative stress, cell cultivation, specific growth rate

\section{INTRODUCTION}

Escherichia coli is a widely used model system for the investigation of responses to oxidative stresses (Storz and Imlay 1999, Pomposiello and Demple, 2000, Kren et al., 1988, Farr and Kogoma, 1991). Aerobic organisms preferentially utilize oxygen for respiration and generation of energy for their vital function and proliferation (Inaoka et al., 1998). Due to the aerobiosis, reactive oxygen species (ROS), such as superoxide $\left(\mathrm{O}_{2}^{-}\right)$, hydrogen peroxide $\left(\mathrm{H}_{2} \mathrm{O}_{2}\right)$, hydroxyl radical $(\cdot \mathrm{OH})$ formed in living cells induce cellular damage such as damage to protein, lipids and DNA. Kim et al., 2004a, investigated the plasmid DNA molecules damage by the oxidative stress.

Finkel and Holbrook (2000) reported that ROS is normally generated in organisms relying on oxygen associated metabolisms and a balance between ROS production and its elimination or detoxification is critical to maintain cellular homeostasis. Different antioxidant mechanisms exist in living cells to avoid cellular damages caused by oxidative stresses (Stortz and Imlay, 1999). It was reported that an increase in oxygen concentration results an increase of reactive oxygen species (ROS) generation (Semchyshyn et al, 2005).

In a recent study (Kim, et al., 2004a), it was discovered that proliferation of the SOD (superoxide dismutase) deficient mutant of Escherichia coli IM303 was promoted under oxidative stress induced by photo excited $\mathrm{TiO}_{2}$. From DNA microarray analysis, one of the 'Corresponding author up-regulated genes, $y g g E$, was selected for investigating its biological function. The gene $y g g E$ showed antioxidant ability to suppress the intracellular ROS content both in the culture of E. coli IM303 (14) and its wild-type strain MM294 cells under various oxidative conditions (Christensen, and Ericksen 2002, Finkel and Holbrook, 2000)

In this work, E. coli IM303 (14) carrying the plasmid pYGE and pUC 19 vector respectively was cultured in a bioreactor under aeration with controlled oxygen at atmospheric condition to study the cultural characteristics in terms of cell growth, lag time, ROS content and glucose utilization.

\section{MATERIALS AND METHODS}

\section{Strains and culture conditions}

The plasmid pYGE, which is pUC 19 vector carrying the gene $y g g E$, and the control plasmid pUC19 were used to transform E. coli IM303 (14) cells, respectively, and then the transformed cells were stored at $5{ }^{\circ} \mathrm{C}$ as $15 \%$ glycerol stock until being used. Preculture was carried out in a shaking flask containing $10 \mathrm{ml}$ of LB medium with $50 \mu \mathrm{g} / \mathrm{mL}$ ampicillin at $37{ }^{\circ} \mathrm{C}$ until the cell density reached the OD value in the range of 0.4 to 0.6 at $660 \mathrm{~nm}$ (Kim et al., 2005) . 


\section{Bioreactor set up}

The experimental setup is shown schematically in Figure 1, consisting of oxygen generator and control units. All experiments were carried out in the $2 \mathrm{~L}$ capacity flat bottom bioreactor and mechanically stirred. The stirred tank was fitted with flat blade impellor. The reactor top was closed with a flat glass plate and insulated using glass wool. A mechanical seal was used to the impeller shaft at the top plate. A band heater of $3.0 \mathrm{~kW}$ on full power was mounted close to the external surface of the stirred tank bioreactor. A thermocouple connected to a data acquisition and control unit was used to measure and control the temperature of the liquid phase in the reactor. Dissolved oxygen (DO) and $\mathrm{pH}$ sensors were set in the bioreactor and their values were recorded by a computer system automatically. The cells were cultivated in the bioreactor in the following conditions: $1 \mathrm{~L}$ of M9 medium containing amino acids solution, 50 $\mu \mathrm{g} / \mathrm{mL}$ of ampicillin and $10 \mu \mathrm{mol} / /$ of isopropyl- $\beta-D$ thiogalactopyranoside, $1 \%$ of inoculum (Inaoka et al., 1998), 1.0 L/min (1.0 v/v/m) aeration and $500 \mathrm{rpm}$ agitation. Air/ Oxygen mixture was distributed in the reactor from a sparger at the bottom. The oxygen concentration in the reactor in the range 6 to $6.8 \mathrm{ppm}$ was regulated from the oxygen generator.

\section{Optical density measurement}

The optical density of the cells for growth rate was monitored using a BactoMonitor- BACT-500 at $660 \mathrm{~nm}$ (Intertech, Tokyo, Japan). The measured values of $\mathrm{OD}_{660}$ were converted into dry cell weight (DCW) by using the predetermined equation DCW $(\mathrm{g} / \mathrm{L})=0.415 \mathrm{OD}_{660}$. The glucose concentration in medium was measured by using a BioProfile $^{\mathrm{TM}} 200$ (Yamato Scientific Co., Ltd, Japan). The experimental conditions used in this work are shown in Table 1.

Table 1: Experimental conditions

\begin{tabular}{ll}
\hline Strain: & Escherichia coli IM303 (I4) \\
Plasmid: & pUC19 or pYGE (containing yggE) \\
Medium: & $1.0 \mathrm{~L}$ of Modified M9 (containing 11 amino acid) \\
& with $50 \mu \mathrm{g} / \mathrm{mL}$ of ampicillin and $10 \mathrm{mM} \mathrm{IPTG}$ \\
Aeration: & Air $/ \mathrm{O}_{2} 1.0 \mathrm{~L} / \mathrm{min}$ \\
Agitation: & $500 \mathrm{rpm}$
\end{tabular}

\section{Estimation of ROS content}

A sample culture $\left(0.5 \mathrm{~cm}^{3}\right)$ was withdrawn from the reactor to determine the intracellular ROS content. The cells were collected by centrifugation for $3 \mathrm{~min}$ at $4^{\circ} \mathrm{C}$ and $5000 \mathrm{Xg}$, followed by incubation with $3 \mathrm{~cm}^{3}$ of $10 \mu \mathrm{mol} / \mathrm{dm}^{3}$ 5-(and-6)-chloromethyl-2', 7'-dichlorofluorescindiacetate (C-6827, Molecular Probes Inc., USA) for $1 \mathrm{~h}$ at $37^{\circ} \mathrm{C}$. The ROS content in the cells was quantified with a fluorescence spectrophotometer (Hitachi, Ltd., Japan) at excitation and emission wave lengths of 515 and $530 \mathrm{~nm}$, respectively(Navdeep et al.,2000) and it was expressed as $\mathrm{H}_{2} \mathrm{O}_{2}$ equivalent by means of standard line.

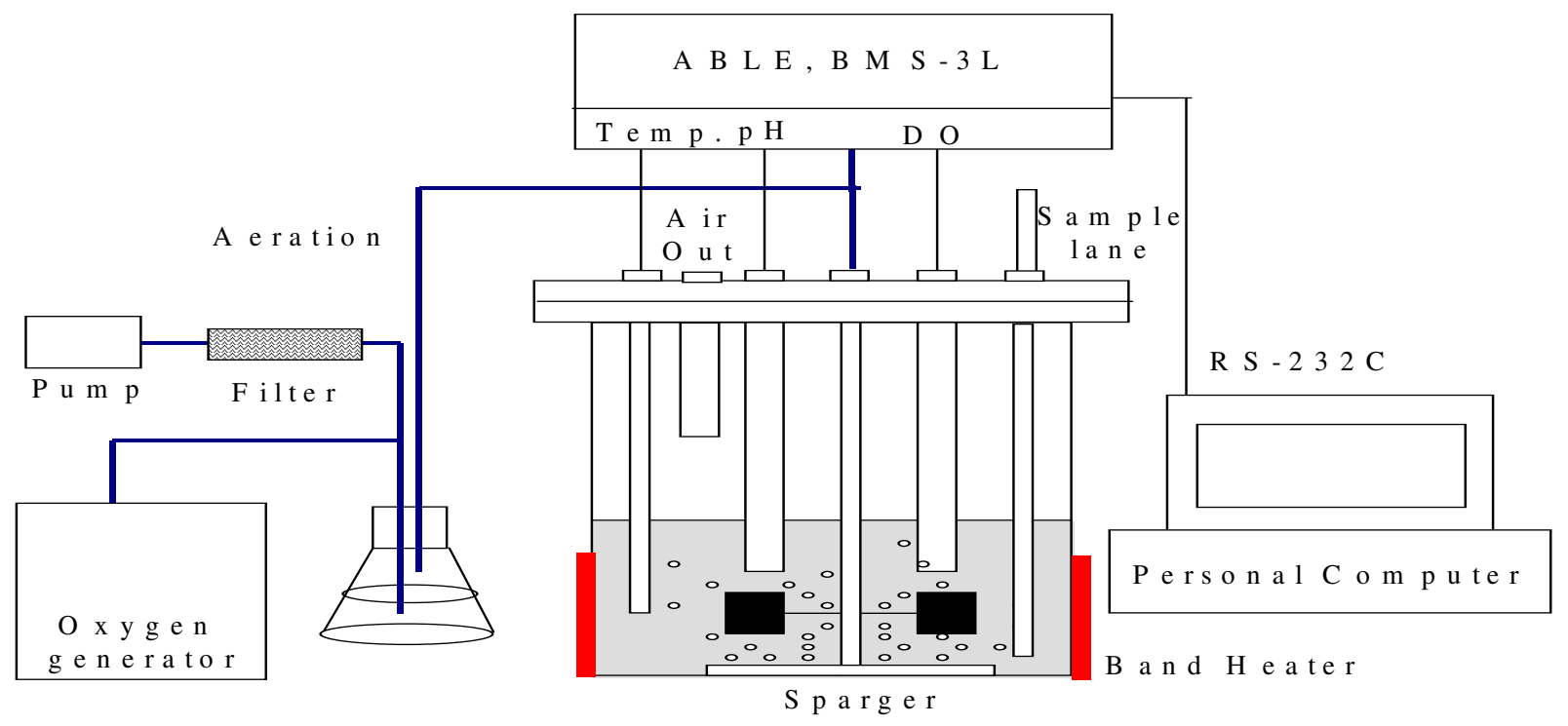

Figure 1: Experimental setup of the bioreactor 


\section{RESULTS AND DISCUSSION}

\section{Effect of dissolved oxygen concentration}

Pure oxygen mixed with air is used in this work to attain fast equilibrium state during the entire experiment period. The cultural characteristics of the cells of gene product are influenced by $\mathrm{DO}$ and $\mathrm{pH}$ the two principal variables that influence the cell density with time (figure 2). DO was varied in the range 6.0-6.8 ppm by controlling the oxygen flow rate and $\mathrm{pH}$ was controlled in the range of 6.0 to 7.0. As shown in Figure 2, the DO concentration of cells carrying pUC 19 is higher than PYGE during the period studied. While insignificant difference was observed with respect to $\mathrm{pH}$.

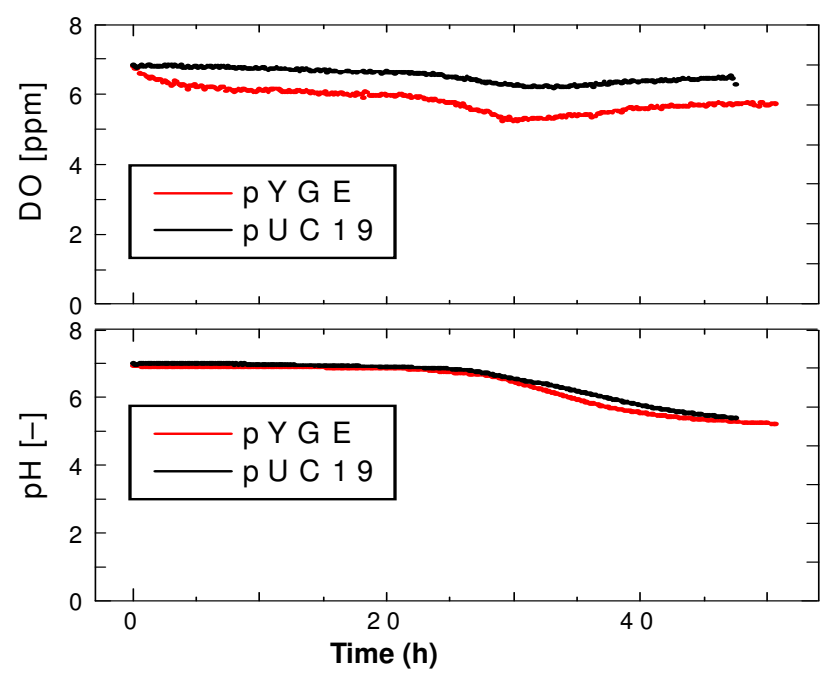

Figure 2: $\mathrm{DO}$ and $\mathrm{pH}$ values during the culture growth

\section{Overall cell yield with glucose}

Table 2 shows the overall cell yield. Maximum dry cell weight obtained at the stationary phase and maximum specific growth rate $\left(\mu_{\mathrm{m}}\right)$ of E. coli IM303 (14) carrying pYGE were significantly higher than those of the cells carrying pUC19 as shown in Table 2. Overall cell yield on glucose ( $\left.Y_{\mathrm{X} / \mathrm{S}}\right)$ of E. coli IM303 (14) carrying pYGE was 1.5 times higher than that of the cells carrying pUC 19, indicating that the cell carrying pYGE can grow effectively under the dissolved oxygen concentration in the range 6.0 to $6.8 \mathrm{ppm}$, which seems sufficient to provide stress to SOD-deficient cells. This suggests that adaptive mechanisms to high level in E. coli with pYGE are lower than in pUC 19, although it was reported that several antioxidant systems exist in living cells to avoid cellular damages caused by oxidative stresses (Storz and Imlay, 1999, Sun et al., 2004). The maximum specific growth rate was obtained for both pUC19 and pYGE cultures.

Table 2: Overall yield of dry cell mass with glucose

\begin{tabular}{lc}
\hline Transformant & $Y_{\mathrm{X} / \mathrm{s}}$ [DCW-g/glucose-g] \\
\hline E. coli IM303(I4) with pYGE & 0.157 \\
E. coli IM303(I4) with pUC 19 & 0.109 \\
E. coli IM303(I4) with plasmid & 0.108 \\
\hline
\end{tabular}

\section{Specific growth rate}

The growth profiles of E. coli IM303 (14) carrying pUC19 and pYGE were plotted (figure 3 ) and maximum specific growth rate $\mu_{\mathrm{m}}$ and lag time $\mathrm{t}_{\mathrm{L}}$ were determined. The parameters were estimated from the obtained growth profiles by fitting the data to the modified Gompertz equation (Zwietering et al, 1990) with linear least square method using the Microsoft XL software by the equation (1):

$$
X=X_{\mathrm{m}} \exp \left\{-\exp \left[\frac{\mu_{\mathrm{m}} e}{X_{\mathrm{m}}}\left(t_{\mathrm{L}}-t\right)+1\right]\right\}
$$

Where $X=$ cell growth recorded at $\mathrm{OD}_{660}[-], \mathrm{X}_{\mathrm{m}}=$ maximum cell density $[\mathrm{g} / \mathrm{l}]$ and $t=$ culture time $(\mathrm{h})$.

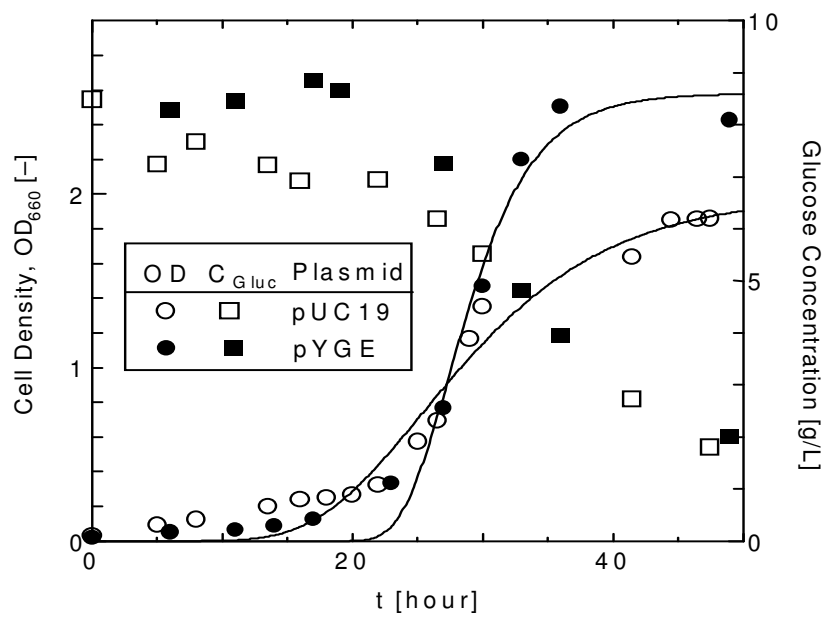

Figure 3: Cell growth rate and density effect on glucose

Both the strains cultivated under various conditions showed significant difference in the $\mu_{\mathrm{m}}$ values Table 3 . It is evident that the length of lag time is proportional to the inverse of maximum specific growth rate. The analysis of data presented in Table 3 indicates that cell density is not the same for the tested two plasmids. The cell growth rate 
can be linked to an intracellular ROS level, which may be fluctuated in response to oxidative stress against cells.

Table 3: Parameters by fitting the Gompertz equation

\begin{tabular}{llll}
\hline Condition & $\begin{array}{l}\text { Maximum cell } \\
\text { density, } \mathbf{X}_{\mathbf{m}} \\
{[\mathbf{g} / \mathrm{L}]}\end{array}$ & $\begin{array}{l}\text { Maximum specific } \\
\text { growth rate, } \boldsymbol{\mu}_{\mathbf{m}}\left[\mathbf{h}^{-1}\right]\end{array}$ & $\mathbf{t}_{\mathrm{L}}[\mathrm{h}]$ \\
\hline pUC 19 & 0.74 & 0.05 & 21.9 \\
pYGE & 1.06 & 0.11 & 12.5 \\
\hline
\end{tabular}

\section{ROS content at different phases of cell growth}

The intracellular ROS content obtained with two transformants of E. coli IM303 (I4) cells carrying pUC 19 and PYGE respectively was compared. As indicated in Figure 4, the control cells with pUC 19 showed relatively high ROS level in the early exponential growth phase $\left(\mathrm{OD}_{660=0.3}\right)$. The ROS content in IM303 (14) cells with pUC 19 was further increased when the cells entered in the middle exponential growth phase $\left(O D_{660=0.7}\right)$, however ROS content decreased at $O_{660=1.4}$. In contrast to this, in the case of IM 303 (14) cells carrying PYGE, the ROS content was about $76 \%$ of that in the control cells with pUC

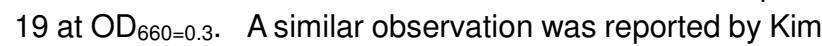
et al., 2005, that $\mathrm{ROS}$ such as $\mathrm{O}_{2}^{-}$is in excess accumulated to damage the SOD-deficient cells when cultivated with oxygen supply under an aerobic condition, but the ROS level in the cells with pYGE was approximately $31 \%$ of that in the control cells carrying pUC 19.

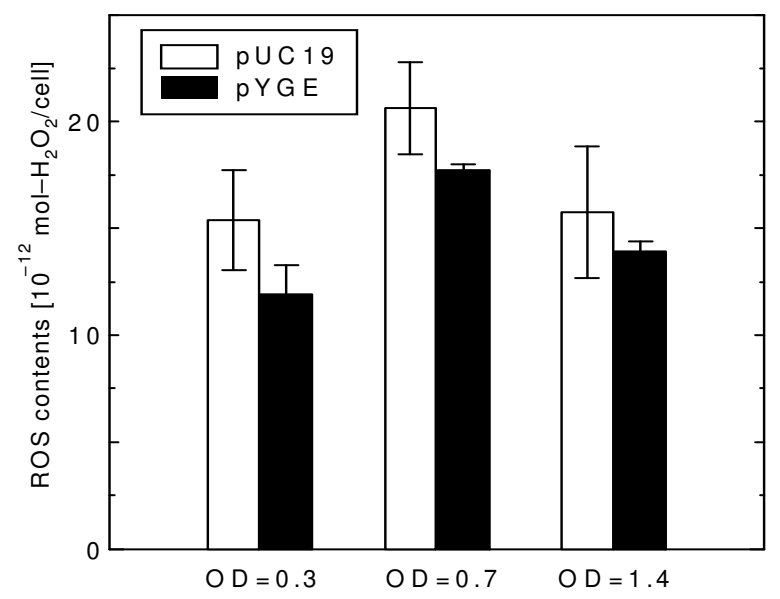

Figure 4: Effect of ROS at different optical density

\section{CONCLUSIONS}

In the present study, it was found that the E. coli IM303(14) carrying pUC 19 and pYGE are different in their abilities to grow under conditions of varying oxygen supply. The maximum cell density $\left(X_{\mathrm{m}}\right)$, maximum specific growth rate $\left(\mu_{\mathrm{m}}\right)$ and lag time $\left(t_{\mathrm{L}}\right)$ were found for both transformants. It was also found that the DO values were varied with pUC19 than pYGE and the ROS content of pUC19 was found to be higher than $P Y G E$.

\section{ACKNOWLEDGEMENT}

One of the authors (DK) thank the Director, International Centre for Biotechnology, Osaka University, Japan for supporting the research and providing the necessity facilities and Prof. Masahito Taya, Department of Chemical Science and Engineering for valuable suggestions.

\section{REFERENCES}

Christensen, M.L. and Eriksen, N.T. (2002). Growth and proton exchange in recombinant Escherichia coli BL21. Enzyme and Microbial Technology. 31: 566-574.

Finkel, T. and Holbrook, N. J. (2000). Oxidants, oxidative stress and the biology of ageing. Nature. 408: 239-247.

Farr, S.B. and Kogoma, T. (1991). Oxidative stress responses in Escherichia coli and Salmonella typhimurium. Microbiol.Rev. 55: 561-585.

Inaoka, T., Matsumura, Y. and Tsuchido, T. (1998). Molecular cloning and nucleotide sequence of the superoxide dismutase-deficient mutant of Escherichia coli. J.Bacteriol. 174: 953-961.

Kim, S.Y., Nishioka, M. Hayashi, S. Honda, H, Kobayashi, T. and Taya, M. (2005). The gene yggE functions in restoring physiological defects of Escherichia coli cultivated under oxidative stress conditions. Appl. Environ. Microbiol. 71(5): 2762-2765.

Kim, S.Y., Nishioka, M. and Taya, M. (2004a). Promoted proliferation of SOD -deficient mutant of Escherichia coli under oxidative stress induced by photoexicited TiO2. FEMS Microbial Lett. 236: 109-114.

Kren, B., Parsell, D. and Fuchs, J.A. (1988). Isolationand characterization of an Escherichia coli K-12 mutant deficient in glutaredoxin. J.Bacteriol. 170: 308-315.

Navdeep, S. C., McClintock, D.S. Feliciano, C.E, Wood, T.M, Andres M.J, Rodriguez, A.M and Schumacker, P.T. (2000). Reactive Oxygen Species Generated at Mitochondrial Complex III Stabilize Hypoxia-inducible Factor-1 a during Hypoxia. J. Biol. Chem. 275: (33): 25130-25138.

Pomposiello, P.J. and Demple, B. (2000). Encyclopedia of Microbiology 2nd Ed, Vol 3, Academic Press, New 
York. pp.78-84.

Semchyshyn, M., Lushchak, V. and Storey, K. (2005). Possible reasons for difference in sensitivity to oxygen of two Escherichia coli strains. Biochemistry (Moscow). 70: 424-431.

Storz, G. and Imlay, J.A. (1999). Oxidative stress. Curr.Opin.Microbiol. 2: 188-194.

Kim, S.Y., Taguchi, T, Nishioka, M. and Taya. M. (2004b). Quantitative assessment of DNA damage accompanied with no substantial loss in its molecular weight during exposure to oxidative stress. Biochemical Engineering Journal. 22: 81-87.

Zwietering, M.H., Joongenburger, L, Rombouts, F.M and van't Riet, K. (1990). Modeling of the bacterial growth curve. Appl.Environ. Microbiol. 56: 1875-1881. 